\title{
Co-Catalytic Effect of Nanostructured Ruthenium Oxide Towards Electro-Oxidation of Methanol and Carbon Monoxide
}

\author{
Wataru Sugimoto, ${ }^{*}$ Takahiro Saida and Yoshio Takasu \\ Department of Fine Materials Engineering, Faculty of Textile Science and Technology, Shinshu \\ University, 3-15-1 Tokida, Ueda 386-8567, JAPAN
}

\begin{abstract}
Carbon supported platinum (Pt/C) modified with nanostructured ruthenium oxide was prepared and the activity towards the electro-oxidation of methanol and pre-adsorbed carbon monoxide was studied. Electrochemical studies at $60^{\circ} \mathrm{C}$ in $0.5 \mathrm{M} \mathrm{H}_{2} \mathrm{SO}_{4}$ indicated that the addition of crystalline ruthenic acid nanosheets (HROns) as a co-catalyst to $\mathrm{Pt} / \mathrm{C}$ promotes both methanol and carbon monoxide electro-oxidation. The increase in the activity of HROns modified Pt/C compared to Pt/C is suggested to be a result of the bi-functional characteristic of the surface of the oxide nanosheets.
\end{abstract}

KEYWORDS: Direct methanol fuel cell; Carbon monoxide; Platinum; Ruthenium oxide; Electrocatalyst; Nanosheet

\footnotetext{
* Corresponding author. Tel.: +81-268-21-5455; fax: +81-268-21-5452. E-mail address: wsugi@shinshu-u.ac.jp (W. Sugimoto).
} 


\section{Introduction}

Carbon supported platinum-ruthenium alloys $(\mathrm{PtRu} / \mathrm{C})$ are one of the most promising anode catalysts for direct methanol fuel cells (DMFCs) [1-18]. The promotion effect has been mainly discussed based on the so-called "bi-functional effect" [19-21] or "ligand effect" [22] or a mixture of both. The bi-functional mechanism proposes that Ru promotes the oxidation of adsorbed carbon monoxide $\left(\mathrm{CO}_{\mathrm{ad}}\right)$ on Pt by supplying an oxygen source $\left(\mathrm{Ru}-\mathrm{OH}_{\mathrm{ad}}\right)$. According to the ligand effect, the electronic state of the catalyst is changed so that the binding strength of $\mathrm{CO}_{\mathrm{ad}}$ is weakened, thereby reducing the oxidation overpotential. One of the problems associated with such electrocatalysts is the instability of the co-catalyst $\mathrm{Ru}$, which is irreversibly oxidized at potentials higher than 0.8 V vs RHE [23-27]. Recent studies have also shown that dissolution of metals from the catalyst layer occurs under fuel cell operation [28-31], which may lead to unsolicited reduction of catalyst activity and membrane failure.

One way to overcome this difficulty may be the use of electrochemically stable ruthenium oxides. The possibility of ruthenium oxides $\left(\mathrm{RuO}_{x}\right.$ or $\left.\mathrm{RuO}_{x} \mathrm{H}_{y}\right)$ acting as co-catalysts has attracted recent interest and debate [32-40]. One reason for the apparent inconsistency in the reported literature may be due to the various forms of ruthenium oxide with different oxidation states and hydrous states having different electrochemical characteristics. Oxides with tetravalent ruthenium (e.g. $\mathrm{RuO}_{2}, \mathrm{RuO}_{2} \cdot n \mathrm{H}_{2} \mathrm{O}, \mathrm{H}_{0.2} \mathrm{RuO}_{2.1} \cdot x \mathrm{H}_{2} \mathrm{O}$ ) are known to be electrochemically stable within the hydrogen and oxygen evolution region, thereby are promising electrode materials for electrochemical supercapacitors [41-47]. The surface redox behavior of these materials are sensitive to the chemical composition and microstructure [46]. We recently succeeded in the preparation of crystalline ruthenic acid nanosheets derived from $\mathrm{H}_{0.2} \mathrm{RuO}_{2.1} \times x \mathrm{H}_{2} \mathrm{O}$. The crystalline 
oxide nanosheets $\left.\left(\mathrm{H}_{0.2-\alpha} \mathrm{RuO}_{2.1}\right)^{(0.2-\alpha)-}\right)$ are negatively charged with $0.4 \mathrm{~nm}$ thickness, stabilized as a colloid in solution by tetrabutylammonium counter ions [43]. Ruthenic acid nanosheet electrodes have excellent electrochemical stability and are excellent proton-electron conductors. Due to the atomic level thickness of the nanosheets combined with the negative charge, the nanosheets can be considered as an inorganic macro anion [47].

Here we report the use of crystalline ruthenic acid nanosheets derived from $\mathrm{H}_{0.2} \mathrm{RuO}_{2.1} \cdot x \mathrm{H}_{2} \mathrm{O}$ as a co-catalyst for platinum towards $\mathrm{CH}_{3} \mathrm{OH}$ and $\mathrm{CO}$ electro-oxidation in an acidic environment.

\section{Experimental Section}

The ruthenic acid nanosheet colloid was prepared following a procedure to an earlier report [43]. Briefly, layered ruthenic acid hydrate $\left(\mathrm{H}_{0.2} \mathrm{RuO}_{2.1} \cdot x \mathrm{H}_{2} \mathrm{O}\right)$ was obtained by acid treatment of layered potassium ruthenate $\left(\mathrm{K}_{0.2} \mathrm{RuO}_{2.1} \cdot x \mathrm{H}_{2} \mathrm{O}\right)$. Ethylammonium-ruthenic acid intercalation compound was prepared by reaction of $\mathrm{H}_{0.2} \mathrm{RuO}_{2.1} \cdot x \mathrm{H}_{2} \mathrm{O}$ with $50 \%$ ethylamine aqueous solution. Tetrabutylammonium-layered ruthenic acid intercalation compound was prepared by reaction of the ethylammonium-ruthenic acid intercalation compound with $10 \%$ tetrabutylammonium hydroxide aqueous solution at room temperature for $50 \mathrm{~h}$. The solid product was centrifugally collected (15,000 rpm) and dispersed in distilled water. The suspension was subject to ultrasonification for 30 minutes and centrifuged at $2000 \mathrm{rpm}$. The supernatant colloid, which contains ruthenic acid nanosheets (HROns) stabilized by tetrabutylammonium cations, was used for further investigation.

Carbon supported Pt (30 mass\% Pt) was prepared by an impregnation method reported previously [10]. Briefly, an appropriate amount of Vulcan XC-72R was mixed with $\mathrm{Pt}\left(\mathrm{NH}_{3}\right)_{2}\left(\mathrm{NO}_{2}\right)_{2}$ dissolved in ethanol then allowed to dry to a powder at $60^{\circ} \mathrm{C}$. The dried powder was then reduced 
in a tube furnace under flowing $\mathrm{H}_{2}(10 \%)-\mathrm{N}_{2}(90 \%)$ gas for $2 \mathrm{~h}$ at $200^{\circ} \mathrm{C}$. $\mathrm{Pt} / \mathrm{C}$ powder was added into the colloid suspension containing HROns and thoroughly mixed at room temperature. The amount of Pt/C added to the HROns colloid was set so that the atomic ratio in the catalyst would be $\mathrm{Pt}: \mathrm{Ru}=1: 0.5$ (Pt; 27.2 mass\%, $\mathrm{RuO}_{2}$; 9.3 mass\%). Reaction of Pt/C with HROns was realized by sedimentation. The mixture was then dried at $80^{\circ} \mathrm{C}$ to obtain the final product, ruthenic acid nanosheet modified carbon supported platinum (HROns/Pt/C). HROns/C (10 mass\% $\mathrm{RuO}_{2}$ ) was prepared similarly, except pristine Vulcan was used instead of Pt/C.

The working electrode was prepared by depositing $40 \mu \mathrm{g}$ of the electrocatalyst on a mirror-polished glassy carbon $\operatorname{rod}\left(0.196 \mathrm{~cm}^{2}\right.$ exposed surface) with a micropipette. $20 \mu \mathrm{L}$ of a 1 wt\% Nafion ionomer (resulting in a calculated Nafion thickness of $\sim 4.5 \mu \mathrm{m}$ ) was dropped onto the electrode surface to stabilize the electrocatalysts. A beaker-type electrochemical cell equipped with the working electrode, a platinum mesh counter electrode, and an $\mathrm{Ag} / \mathrm{AgCl}$ reference electrode was used. A Luggin capillary faced the working electrode at a distance of $2 \mathrm{~mm}$. All electrochemical measurements were conducted at $60^{\circ} \mathrm{C}$. All electrode potentials will be referred to the RHE scale at $60^{\circ} \mathrm{C}$.

The electro-oxidation of methanol was characterized by chronoamperometry at $500 \mathrm{mV}$ in 0.5 $\mathrm{M} \mathrm{H}_{2} \mathrm{SO}_{4}+1 \mathrm{M} \mathrm{CH}_{3} \mathrm{OH}$ solution. Voltammetry was conducted after the chronoamperometry measurements at a scan rate of $10 \mathrm{mV} \mathrm{s}^{-1}$. Electro-oxidation of pre-adsorbed carbon monoxide ( $\mathrm{CO}_{\mathrm{ad}}$ ) was measured by $\mathrm{CO}_{\mathrm{ad}}$ stripping voltammetry in $0.5 \mathrm{M} \mathrm{H}_{2} \mathrm{SO}_{4}$ solution at a scan rate of 10 $\mathrm{mV} \mathrm{s}^{-1}$. Adsorption of $\mathrm{CO}$ onto the electrocatalysts was conducted by purging $\mathrm{CO}$ gas into the cell for 40 minutes while maintaining a constant voltage of $50 \mathrm{mV}$. Excess $\mathrm{CO}$ in the electrolyte was then purged out with $\mathrm{N}_{2}$ for $40 \mathrm{~min}$. The amount of $\mathrm{CO}_{\mathrm{ad}}$ was calculated assuming a monolayer of 
linearly adsorbed CO and the Coulombic charge necessary for oxidation as $420 \mu \mathrm{C} \mathrm{cm}{ }^{-2}$, corrected for the electrical double-layer capacitance.

\section{Results and Discussion}

The cyclic voltammogram (CV) of HROns/C in $0.5 \mathrm{M} \mathrm{H}_{2} \mathrm{SO}_{4}$ is shown in Fig. 1 (a). The CV of HROns/C is characterized by a combination of the pseudocapacitance of HROns and the electric double layer capacitance of carbon. Redox peaks distinctive of HROns are clearly observed. The redox peaks at $E_{1 / 2} \sim 0.62$ and $0.81 \mathrm{~V}$ are attributed to electrosorption of anions and cations on the HROns surface, respectively [45]. The origin of the redox pair at $E_{1 / 2} \sim 0.11 \mathrm{~V}$ is presently not clear. The capacitance of HROns/C is $108 \mathrm{~F}$ (g-catalyst) ${ }^{-1}$. The pseudocapacitive contribution from HROns after subtraction of the electric-double layer capacitance from carbon $\left(47 \mathrm{~F} \mathrm{~g}^{-1}\right)$ is $662 \mathrm{~F}$ $\left(\mathrm{g}-\mathrm{RuO}_{2}\right)^{-1}$. This value is comparable to pristine HROns [43], indicating the complete electrochemical accessibility of HROns in HROns/C. The CV of HROns/C in $0.5 \mathrm{M} \mathrm{H}_{2} \mathrm{SO}_{4}+1 \mathrm{M}$ $\mathrm{CH}_{3} \mathrm{OH}$ (Fig. 1 (b)) reveals oxidation currents only above $1.0 \mathrm{~V}$, indicating that HROns/C is a poor $\mathrm{CH}_{3} \mathrm{OH}$ electro-oxidation catalyst. The $\mathrm{CO}$ stripping voltammogram is shown in Fig. 1 (c). The voltammogram is identical to the base voltammogram in $0.5 \mathrm{M} \mathrm{H}_{2} \mathrm{SO}_{4}$ (Fig. 1 (a)), which indicates that the interaction between $\mathrm{CO}$ and the HROns surface is weak and CO cannot adsorb on the surface of HROns.

CVs of $\mathrm{HROns} / \mathrm{Pt} / \mathrm{C}$ and $\mathrm{Pt} / \mathrm{C}$ in $0.5 \mathrm{M} \mathrm{H}_{2} \mathrm{SO}_{4}$ are compared in Fig. 2. The $\mathrm{CV}$ of $\mathrm{HROns} / \mathrm{Pt} / \mathrm{C}$ reveals features of both HROns and Pt. Voltammograms in $0.5 \mathrm{M} \mathrm{H}_{2} \mathrm{SO}_{4}+1 \mathrm{M} \mathrm{CH}_{3} \mathrm{OH}$ for HROns/Pt/C and Pt/C are compared in Fig. 3. The onset potential of $\mathrm{CH}_{3} \mathrm{OH}$ oxidation for HROns/Pt/C is approximately $400 \mathrm{mV}$, which is $100-150 \mathrm{mV}$ lower than Pt/C. Chronoamperometry 
data in $0.5 \mathrm{M} \mathrm{H}_{2} \mathrm{SO}_{4}+1 \mathrm{M} \mathrm{CH}_{3} \mathrm{OH}$ at $500 \mathrm{mV}$ for HROns/Pt/C and Pt/C are shown in the inset of Fig. 3. The mass activity after $30 \mathrm{~min}$ for HROns/Pt/C was $42 \mathrm{~A}(\mathrm{~g}-\mathrm{Pt})^{-1}$. This is almost 4 times higher than that of Pt/C.

The $\mathrm{CO}_{\mathrm{ad}}$ stripping voltammograms of $\mathrm{HROns} / \mathrm{Pt} / \mathrm{C}$ and $\mathrm{Pt} / \mathrm{C}$ are presented in Fig. 4. The $\mathrm{CO}_{\mathrm{ad}}$ stripping voltammograms of HROns/Pt/C clearly shows CO adsorption occurs on the Pt surface. The electrochemically active surface area calculated from the $\mathrm{CO}_{\mathrm{ad}}$ oxidation current for HROns/Pt/C and Pt/C was 85 and $75 \mathrm{~m}^{2}$ (g-Pt) ${ }^{-1}$, respectively. The co-catalytic effect of HROns is undoubtedly shown by a less positive shift in the onset potential for $\mathrm{CO}_{\mathrm{ad}}$ oxidation of $\sim 200 \mathrm{mV}$. Since HROns is a poor $\mathrm{CH}_{3} \mathrm{OH}$ and $\mathrm{CO}_{\text {ad }}$ electro-oxidation catalyst, the results are a clear indication of the bi-functional effect of the surface of HROns.

Besides the improved $\mathrm{CH}_{3} \mathrm{OH}$ and $\mathrm{CO}$ electro-oxidation properties of $\mathrm{HROns} / \mathrm{Pt} / \mathrm{C}$, the stability of HROns should also be noted. As aforementioned, Ru metal in a conventional PtRu alloy is readily oxidized at potentials higher than $0.8 \mathrm{~V}$ vs $\mathrm{RHE}$. Cross-leak $\mathrm{O}_{2}$ from the cathode may also accelerate $\mathrm{Ru}$ oxidation. The partial oxidation of $\mathrm{Ru}$ species not only reduces the active metal surface area, but also is vulnerable to dissolution under fuel cell conditions. Such phenomenon results in a decrease in the activity of the electrocatalyst and severely damages the polymer electrolyte membrane. For the case of HROns/Pt/C, HROns is stable within the hydrogen and oxygen evolution. Thus, the HROns/Pt/C system seems to be promising as stable anode and cathode catalysts for DMFC as well as reformate PEM fuel cells.

The presented results clearly indicate that although HROns itself does not act as electrocatalysts for $\mathrm{CH}_{3} \mathrm{OH}$ and $\mathrm{CO}_{\text {ad }}$ electro-oxidation, it performs as an excellent co-catalyst for Pt. That is, the HROns surface can supply -OH to oxidize neighboring Pt-CO, the well-known bi-functional effect. 
Comparison of HROns/Pt/C with conventional $\mathrm{Pt}_{50} \mathrm{Ru}_{50} / \mathrm{C}$ (30 mass\% metal) reveals that, at present, the effect of HROns functionalization is lower than $\mathrm{Ru}$ in conventional alloys under similar experimental conditions (Fig. 3c). The lack of electronic interaction between Pt and HROns (ligand effect), longer distance between Pt and HROns, and difference in water activation on HROns may be possible reasons. However, it must be stressed that the stability of HROns/Pt/C is considerably enhanced. Obviously, further studies are needed to understand the mechanism of the co-catalytic effect. Composition dependency and durability assessment in various electrochemical environments are currently under investigation.

\section{Conclusions}

The effect of the modification of Pt/C with crystalline ruthenic acid nanosheets (HROns) towards the electro-oxidation of methanol and pre-adsorbed carbon monoxide was studied. The experimental results indicate that the modification of Pt/C with HROns decreases the overpotential for $\mathrm{CH}_{3} \mathrm{OH}$ electro-oxidation by $\sim 150 \mathrm{mV}$ and $\mathrm{CO}$ electro-oxidation by $\sim 200 \mathrm{mV}$. A four-fold increase in methanol electro-oxidation activity was obtained from chronoamperometry at $500 \mathrm{mV}$. The increase in the activity is suggested to be a result of the bi-functional characteristic of the surface of the HROns. The present electrocatalyst is expected to provide superior durability compared to conventional PtRu/C under fuel cell operating conditions due to the electrochemical stability of HROns.

Acknowledgements. The authors are grateful to Ishifuku Metal Industry Co. for kindly supplying Pt(NH3) $)_{2}\left(\mathrm{NO}_{2}\right)_{2}$. This work was supported in part by a Polymer Electrolyte Fuel Cell Program 
from the New Energy and Industrial Technology Development Organization (NEDO) of Japan, in collaboration with Toray Industries, Inc.

\section{References}

[1] B.D. McNicol, R.T. Short, J. Electroanal. Chem. 81 (1977) 249.

[2] M. Watanabe, M. Uchida, S. Motoo, J. Electroanal. Chem. 229 (1987) 395.

[3] J.B. Goodenough, A. Hamnett, B.J. Kennedy, R. Manohara, S.A. Weeks, J. Electroanal. Chem. 240 (1988) 133.

[4] A. Hamnett, S.A. Weeks, B.J. Kennedy, G. Troughton, P.A. Christensen, Ber. Bunsen-Ges. Phys. Chem. 94 (1990) 1014.

[5] A.S. Aricò, P. Creti, H. Kim, R. Mantegna, H. Giordano, V. Antonucci, J. Electrochem. Soc. 143 (1996) 3950.

[6] C. He, H.R. Kunz, J.M. Fenton, J. Electrochem. Soc. 144 (1997) 970.

[7] A.S. Aricò, A.K. Shukla, K.M. El-Khatib, P. Creti, V. Antonucci, J. Appl. Electrochem. 29 (1999) 671.

[8] T.J. Schmidt, H.A. Gasteiger, R.J. Behm, Electrochem. Commun. 1 (1999) 1.

[9] A.S. Aricò, P. Creti, E. Modica, G. Monforte, V. Baglio, V. Antonucci, Electrochim. Acta 45 (2000) 4319.

[10] Y. Takasu, T. Fujiwara, Y. Murakami, K. Sasaki, M. Oguri, T. Asaki, W. Sugimoto, J. Electrochem. Soc. 147 (2000) 4421.

[11] H.N. Dinh, X. Ren, F.H. Garzon, P. Zelenay, S. Gottesfeld, J. Electroanal. Chem. 491 (2000) 222. 
[12] Y. Takasu, H. Itaya, T. Iwazaki, R. Miyoshi, T. Ohnuma, W. Sugimoto, Y. Murakami, Chem. Commun. 2001 (2001) 341.

[13] A.V. Tripkovíc, K.D. Popovíc, B.N. Grgur, B. Blizanac, P.N. Ross, N.M. Markovíc, Electrochim. Acta 47 (2002) 3707.

[14] C. Roth, N. Marty, F. Hahn, J.-M. Léger, C. Lamy, H. Fuess, J. Electrochem. Soc. 149 (2002) E433.

[15] Y. Takasu, H. Itaya, T. Kawaguchi, W. Sugimoto, Y. Murakami, Stud. Surf. Sci. Catal. 145 (2003) 279.

[16] Y. Takasu, T. Kawaguchi, W. Sugimoto, Y. Murakami, Electrochim. Acta 48 (2003) 3861.

[17] Y. Takasu, W. Sugimoto, Y. Murakami, Catal. Surveys Asia 7 (2003) 21.

[18] J.O'M. Bockris, H. Wroblowa, J. Electroanal. Chem. 7 (1964) 428.

[19] M. Watanabe, S. Motoo, Denki Kagaku (presently Electrochemistry) 41 (1973) 190.

[20] M. Watanabe, M. Motoo, J. Electroanal. Chem. 60 (1975) 267.

[21] T. Frelink, W. Visscher, J.A.R. van Veen, Surf. Sci. 335 (1995) 353.

[22] T. Yajima, H. Uchida, M. Watanabe, J. Phys. Chem. B 108 (2004) 2654.

[23] S. Hadzi-Jordanov, H. Angerstein-Kozlowska, M. Vukovic, B.E. Conway, J. Electrochem. Soc. 125 (1978) 1473.

[24] D. Mitchell, D.A.J. Rand, R. Woods, J. Electroanal. Chem. 89 (1978) 11.

[25] D.N. Buckley, L.D. Burke, J. Chem. Soc., Faraday Trans. 171 (1975) 1447.

[26] D.N. Buckley, L.D. Burke, J. Chem. Soc., Faraday Trans. 172 (1976) 2431.

[27] V. Birss, R. Myers, H. Angerstein-Kozlowska, B.E. Conway, J. Electrochem. Soc. 131 (1984) 1502. 
[28] P. Piela, C. Eickes, E. Brosha, F. Garzon, P. Zelenay, J. Electrochem. Soc. 151 (2004) A2053.

[29] P.J. Ferreira, G.J. la O’, Y. Shao-Horn, D. Morgan, R. Makharia, S. Kocha, H.A. Gasteiger, J. Electrochem. Soc. 152 (2005) A2256.

[30] P. Yu, M. Pemberton, P. Plasse, J. Power Sources 144 (2005) 11.

[31] W.L. Holstein, H.D. Rosenfeld, J. Phys. Chem. B 109 (2005) 2176.

[32] K. Lasch, L. Jörissen, K.A. Friedrich, J. Garche, J. Solid State Electrochem. 7 (2003) 619.

[33] K. Lasch, G. Hayn, L. Jörissen, J. Garche, O. Besenhardt, J. Power Sources 105 (2002) 305.

[34] D.R. Rolison, P.L. Hagans, K.E. Swider, J.W. Long, Langmuir 15 (1999) 774.

[35] A.H.C. Sirk, J.M. Hill, S.K.Y. Kung, V.I. Birss, J. Phys. Chem. B 108 (2004) 689.

[36] L.X. Yang, R.G. Allen, K. Scott, P.A. Christenson, S. Roy, Electrochim. Acta 50 (2005) 1217.

[37] J.W. Long, R.M. Stroud, K.E. Swider-Lyons, D.R. Rolison, J. Phys. Chem. B 104 (2000) 9772.

[38] Q. Lu, B. Yang, L. Zhuang, J. Lu, J. Phys. Chem. B 109 (2005) 1715.

[39] C. Bock, A. Collier, B. MacDougall, J. Electrochem. Soc. 152 (2005) A2291.

[40] Z. Chen, X. Qiu, B. Lu, S. Zhang, W. Zhu, L. Chen, Electrochem. Commun. 7 (2005) 593.

[41] J.P. Zheng, T.R. Jow, J. Electrochem. Soc. 142 (1995) L6.

[42] J.P. Zheng, P.J. Cyang, T.R. Jow, J. Electrochem. Soc. 142 (1995) 2699.

[43] W. Sugimoto, H. Iwata, Y. Yasunaga, Y. Murakami, Y. Takasu, Angew. Chem. Int. Ed. 42 (2003) 4092.

[44] W. Sugimoto, T. Kizaki, K. Yokoshima, Y. Murakami, Y. Takasu, Electrochim. Acta 49 (2004) 313.

[45] W. Sugimoto, H. Iwata, Y. Murakami, Y. Takasu, J. Electrochem. Soc. 151 (2004) A1181. 
[46] W. Sugimoto, H. Iwata, K. Yokoshima, Y. Murakami, Y. Takasu, J. Phys. Chem. B 109 (2005) 7330.

[47] W. Sugimoto, K. Yokoshima, K. Ohuchi, Y. Murakami, Y. Takasu, J. Electrochem. Soc. in press. 


\section{FIGURE CAPTIONS}

Figure 1. Voltammograms of HROns/C in (a) $0.5 \mathrm{M} \mathrm{H}_{2} \mathrm{SO}_{4}\left(60^{\circ} \mathrm{C}\right)$ and (b) $0.5 \mathrm{M} \mathrm{H}_{2} \mathrm{SO}_{4}+1 \mathrm{M}$ $\mathrm{CH}_{3} \mathrm{OH}\left(60^{\circ} \mathrm{C}\right)$ at $v=10 \mathrm{mV} \mathrm{s}^{-1}$. (c) $\mathrm{CO}$ stripping voltammogram in $0.5 \mathrm{M} \mathrm{H}_{2} \mathrm{SO}_{4}\left(60^{\circ} \mathrm{C}\right)$ at $v=10 \mathrm{mV} \mathrm{s}^{-1}$.

Figure 2. Voltammograms of (a) $\mathrm{Pt} / \mathrm{C}$ and (b) $\mathrm{HROns} / \mathrm{Pt} / \mathrm{C}$ in $0.5 \mathrm{M} \mathrm{H}_{2} \mathrm{SO}_{4}\left(60^{\circ} \mathrm{C}\right.$ ) at $v=10 \mathrm{mV} \mathrm{s}^{-1}$.

Figure 3. Voltammograms of (a) Pt/C, (b) HROns/Pt/C, (c) in-house prepared conventional $\mathrm{Pt}_{50} \mathrm{Ru}_{50} / \mathrm{C}(30 \mathrm{mass} \% \mathrm{PtRu})$ in $0.5 \mathrm{M} \mathrm{H}_{2} \mathrm{SO}_{4}+1 \mathrm{M} \mathrm{CH}_{3} \mathrm{OH}\left(60^{\circ} \mathrm{C}\right)$ at $v=10 \mathrm{mV} \mathrm{s}^{-1}$. Inset shows corresponding chronoamperometry curves at $500 \mathrm{mV}$.

Figure 4. $\mathrm{CO}_{\mathrm{ad}}$ stripping voltammograms of (a) $\mathrm{Pt} / \mathrm{C}$ and (b) $\mathrm{HROns} / \mathrm{Pt} / \mathrm{C}$ in $0.5 \mathrm{M} \mathrm{H}_{2} \mathrm{SO}_{4}\left(60^{\circ} \mathrm{C}\right)$ at $v=10 \mathrm{mV} \mathrm{s}^{-1} .1^{\text {st }}$ scan; solid lines, $2^{\text {nd }}$ scan dotted lines. 


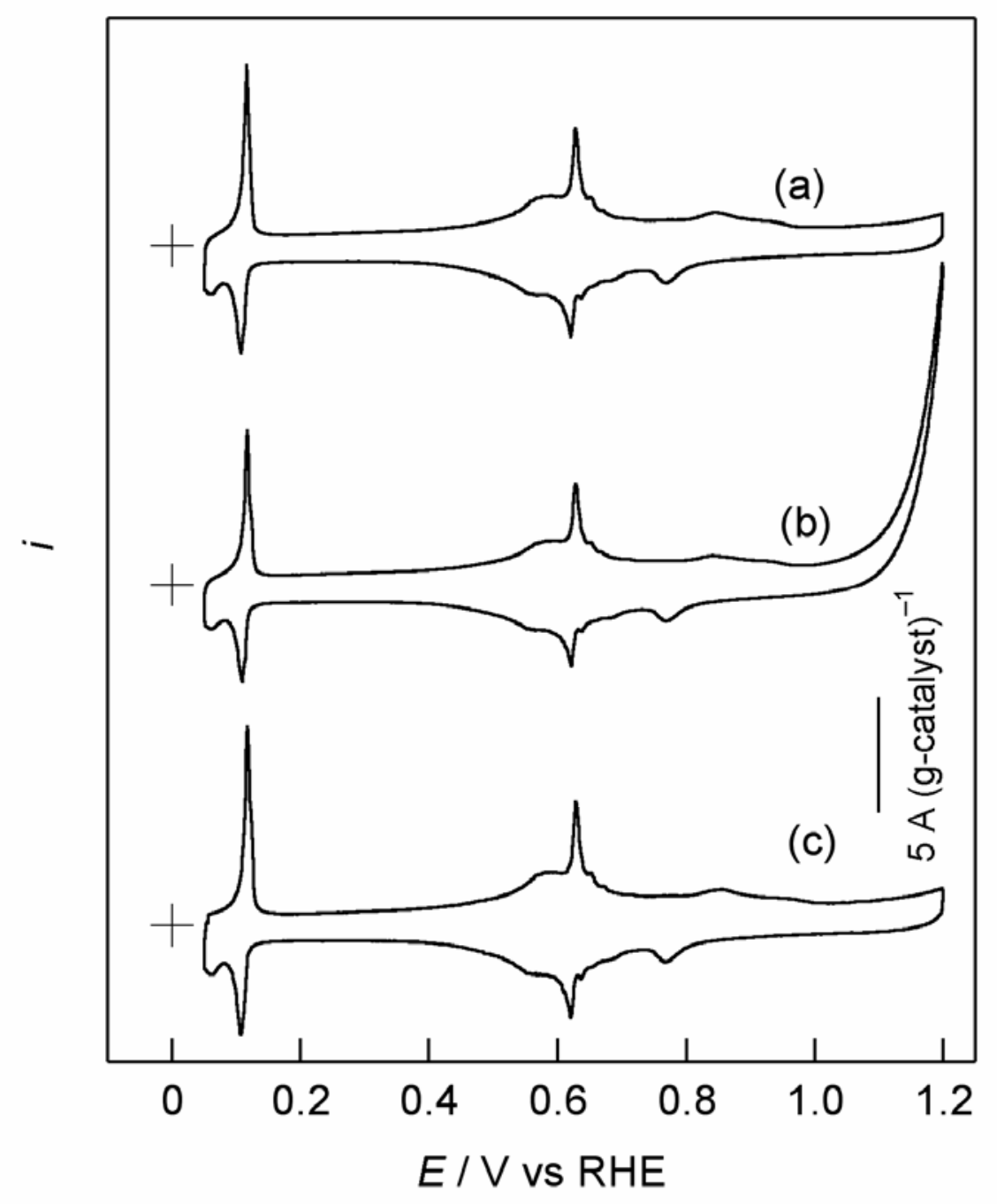

Figure 1 


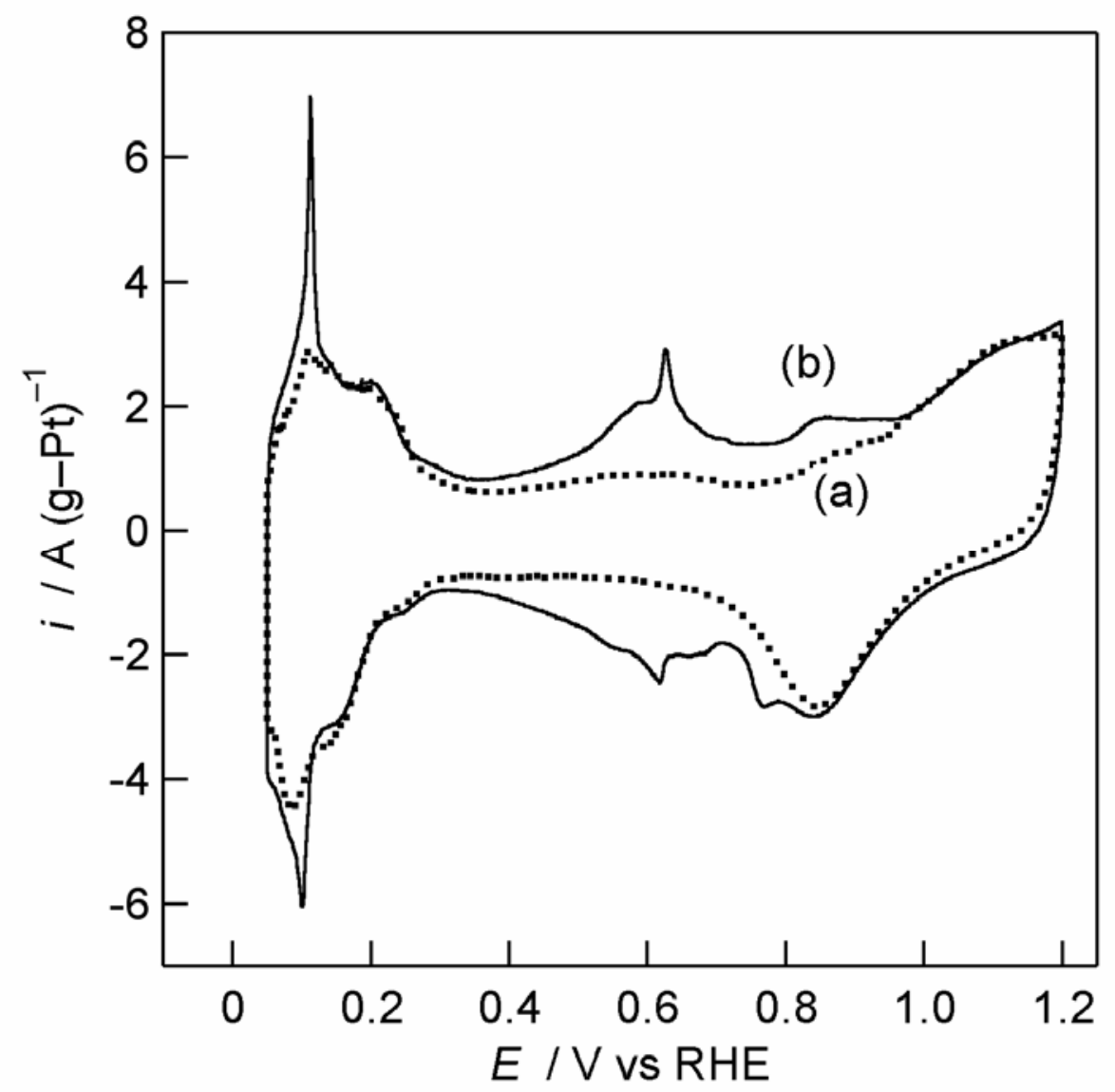

Figure 2 


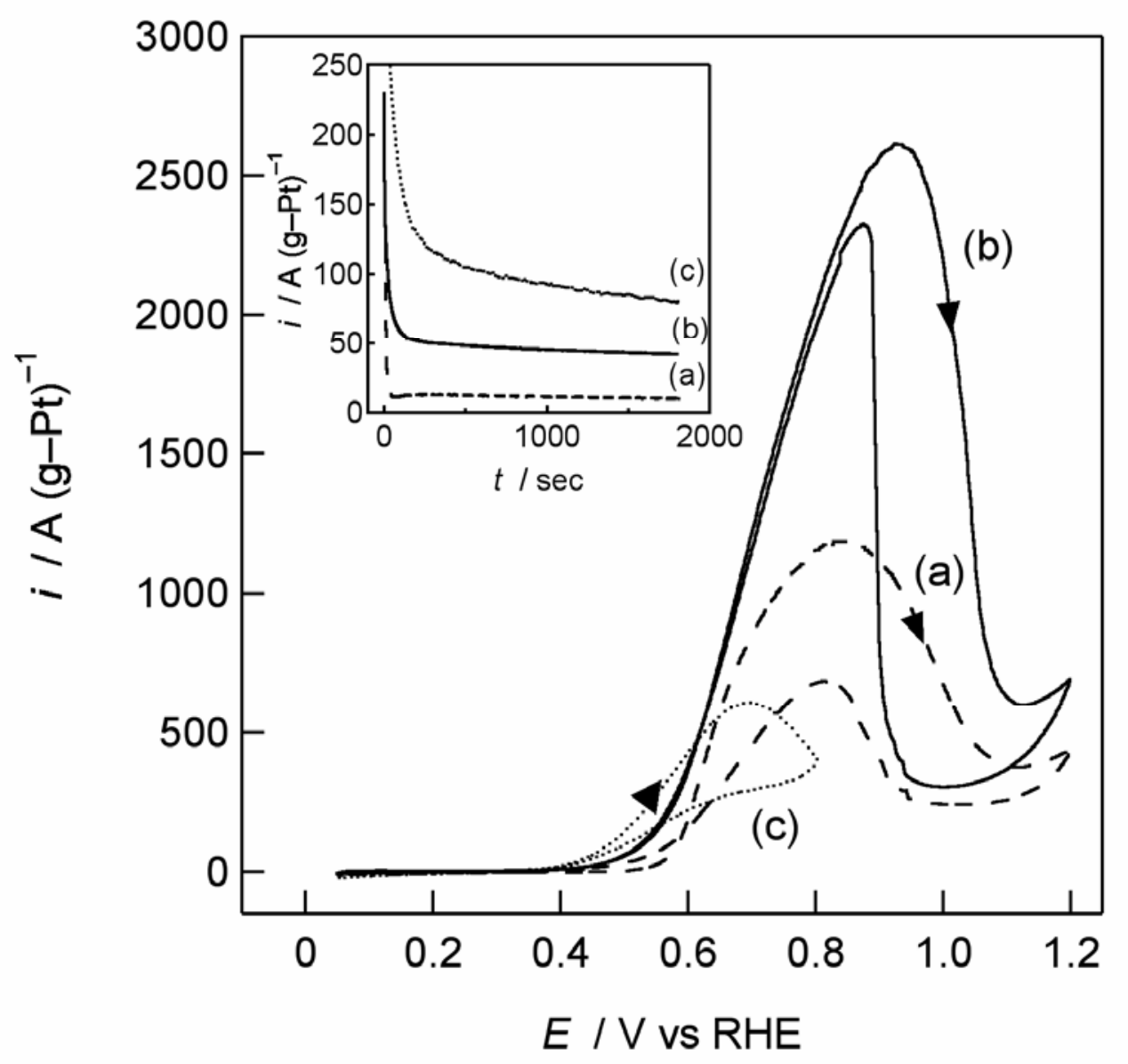

Figure 3 


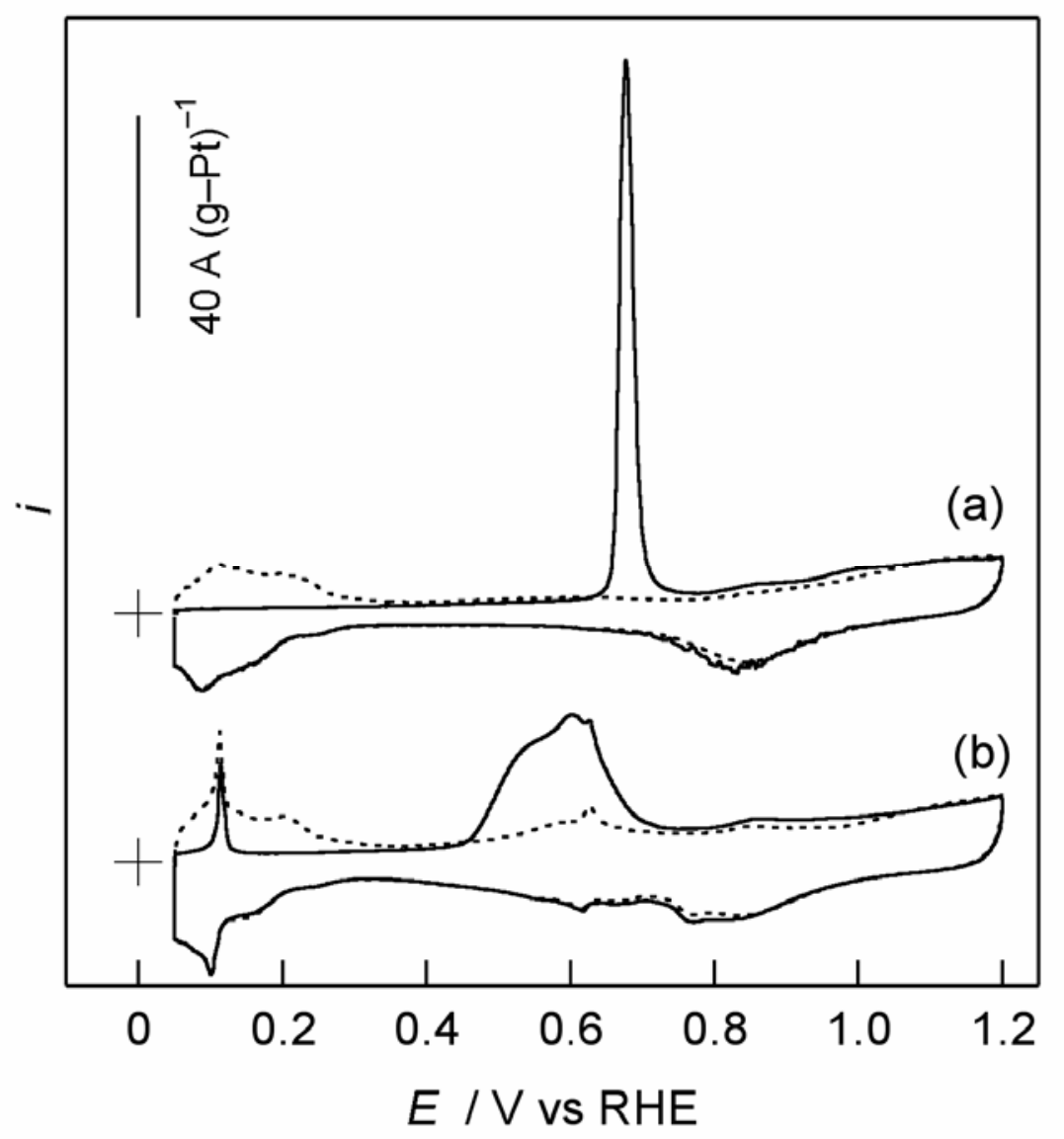

Figure 4 